\title{
Farmers' Perception about 'One House One Farm' Project and Its Impact on Enterprise Profitability in Selected Areas of Mymensingh District
}

\author{
A. Jannat * and M. T. Uddin \\ Institute of Agribusiness and Development Studies (IADS) and \\ Dept. of Agricultural Economics, Bangladesh Agricultural University, Mymensingh-2202, Bangladesh
}

*Corresponding author and Email: arifaecon_bau@yahoo.com

Received: 9 January 2016

Accepted: 12 June 2016

\begin{abstract}
The study was conducted to identify farmers' perception about 'one house one farm' project and its impact on enterprise profitability in Mymensingh district. A total of 90 farmers were selected randomly as the sample of the study for collecting necessary primary data. Forty five farmers under this project and another forty five non-project farmers were selected. Structured questionnaire was used for data collection. Descriptive statistics (i.e., mean, percentages, ratios, etc.), perception index, profitability analysis were employed to attain the objectives. The overall perception of project farmers about 'one house one farm' project was moderate. On the contrary, the perception was slightly moderate for the non-project farmers. The benefit cost ratio was higher for every production enterprise for project farmers than non-project farmers except for large animal rearing. The study identified some problems faced by the farmers in adopting the project as well as who were not adopting this project and probable solutions relating to those problems were also documented.
\end{abstract}

Keywords: 'One house one farm' perception, profitability, enterprise

\section{Introduction}

Bangladesh is a developing country with $6.01 \%$ average growth of GDP (Trading Economics, 2015). 'One house one farm' (Ekti Bari Ekti Khamar) project is one of the important rural development programmes for poverty reduction through ensuring capital formation and skill development of the poor in Bangladesh. This is a top prioritized family farming and poverty reduction program financed by the Government. The intrinsic goal of the project is to reduce national poverty through developing each of the farming household as a unit of agro-economic activities by utilizing human and financial resources of the family members. Small and marginal farmers are the main executor and beneficiaries of this project. The farmers can produce diversified agricultural products which would ensure their food security and economic stability as well.

To achieve sustainable and equitable development is the key considerations of the project which can be eradicate all types of poverty from the society. Out of 25.35 million rural households, $84 \%$ households are small farming families (0.05-2.49 acres). They are producing the lion share (nearly $70 \%$ ) of the agricultural production of the country (Anonymous, 2014). With a view to reach the ultimate goal of this project, Bangladesh Rural 
Development Board (BRDB) identified some mission in order to demonstrate the project vision. The missions of the project are to assist to capital formation of the poor farm families, sharpen their skill by training and motivation, allow them to sit together at courtyard meeting, enable them to take decision independently, enable them to develop need based small family farms and ensure marketing facilities for their product. In the project areas, the heads of the following categories of households were considered as target population: poor womenheaded households in the village, households having only homestead, landless people those who own land up to 0.50 acre of land including homestead, and small and marginal farmers having land area less than 2.50 acres including homestead.

Islam et al. (2013) conducted a research on competency assessment of the farmers on the application of 'one house one farm' approach where the findings indicated that majority of the respondents (94 per cent) had medium competency compared to 2 per cent of them having high competency. On the other hand, there were 4 respondents under low extent of competency. Islam et al. (2011) conducted a study at Dingapota Haor under Mohongonj upazila in Netrokona district. The author examined the profitability of individual farming system namely crop-livestock-poultry-fish catching, crop-livestock-fish catching-labour selling, fish catching-labour selling, croplivestock, crop-livestock-fish catching (C-L-FC) and crop-livestock-poultry. The results showed that the highest average total net return of C-LFC farming system was Tk. 119214 and lowest for C-L-P (crop-livestock-poultry) farming system which was Tk. 25131. Rakib (2012) conducted a comparative economic study on BRRI dhan51 and BR11 production in some selected areas of Mymensingh district. The focuses of the study were the farm-level adoption, differential performances, relative profitability and yield variation of those two rice varieties in the study areas. Gross return of BRRI dhan51 and BR11 rice per hectare were Tk.
99660.8 and Tk. 78953.0 respectively. The average net returns per hectare were found to be Tk. 60638.3 and Tk. 42979.5 which indicated that BRRI dhan51 was more profitable than BR11 rice. Sapna (2012) examined the economic feasibility of 'one house one farm' project idea where the author addressed the performance of all enterprises in existing farming systems which depend on the proper utilization of the existing level of resources. The results showed that relatively better performance was achieved by $\mathrm{C}$ L-P-F system. Ullah et al. (2013) identified and described farmers' problems in practicing 'one house one farm' approach and to explore the relationships between the selected characteristics of the farmers with their problems in practicing 'one house one farm' approach which was carried out in two unions of Mymensingh sadar upazila. The findings revealed that $72 \%$ of the farmers had severe problem, $28 \%$ had moderate problem and none of the farmers faced low problem in practicing this approach. Ullah (2011) carried out a research on farmers' perception towards 'one house one farm' approach in Mymensingh district and measured six parameters such as, food security, economic security, input supply, requirements, components and organizational support. The findings revealed that $47.0 \%$ of the farmers had moderate favourable perception, $28.0 \%$ had less favourable perception and $25.0 \%$ had favourable perception of 'one house one farm' approach.

'One house one farm' project is being implemented for the generation and sustainability of overall management of different production programs as well as marketing, preservation and storage of produced commodities at field level. With the increasing pressure of the growing population, only vertical expansion is possible by integrating appropriate farming components, requiring lesser space and time and ensuring periodic income to the farmer. Because of the scarcity of land, 'one house one farm' is an important option to improve livelihood security of the household members through farming system as well as adoption of different enterprises as farmers are the main 
executor and beneficiaries of this project. The farmers can produce diversified products which will ensure their food security and economic stability as well. For the successful adoption of and sustainability of this project, it is very important to know the perception of the farmers toward this project. To realize, the need for analyzing the perception of the farmers on 'one house one farm' approach and to assess the profitability status of the relevant enterprises under 'one house one farm' project, the present study was undertaken.

The specific objectives of the study are:

i) To identify socioeconomic characteristics of the sample farmers and farmers' perceptions about 'one house one farm' approach;

ii) To determine profitability of different enterprises under 'one house one farm' project; and

iii) To suggest policy options for overcoming constraints and exploring possible opportunities.

\section{Methodology}

The study was conducted during February and March in 2015. An updated list of all the 'one house one farm' farmers were collected from the Deputy Director's (DD) office of the Bangladesh Rural Development Board (BRDB) in Mymensingh district where approximately 1050 'one house one farm' farmers were found in Bhabkhali, Char Nilakshmia and Char Ishwardia union from which 45 farmers were selected randomly. As the study was based on comparing the farmers perception about this project and profitability status i.e., another 45 farmers were selected also randomly. Therefore, a total of 90 farmers were selected as the sample of the study for collecting the data. A questionnaire was developed to document the information which were used for relevant analysis.

\subsection{Analytical technique}

Farmers' perception of 'one house one farm' approach was the focus variable of the study. For measuring the perception of the respondents, a 5- point Likert Scale was used. There were 18 statements comparing both in favour and disfavour (project farmers and non-project farmers) against the 5-point scale. All the statements were arranged randomly under six headings i.e., food security, economic stability, input supply, requirements, competent and organizational support to help avoiding subjects bias in expressing their opinion. Each respondent was asked to indicate the extent of agreement or disagreement against each statement along a 5point scale, i.e., 'strongly agree', 'agree', 'undecided', 'disagree' and 'strongly disagree'. Weights assigned to these responses were 5, 4, 3, 2 and 1 in favour and 1, 2, 3, 4 and 5 in disfavour options. The total score of a respondent was determined by summing up the weights for responses against all the 18 statements. Perception score of a respondent could, thus, range from 18 to 90 . On the other hand, perception score for each respondent was calculated by using Perception Index (Roy, 2009) and it was calculated by using the following formula:

Perception Index $(\mathrm{PI})=5 \times \mathrm{SA}+4 \times \mathrm{A}+3 \times \mathrm{U}+$ $2 \times \mathrm{DA}+1 \times \mathrm{SDA}$ (in favour)

Or

Perception Index $(\mathrm{PI})=1 \times \mathrm{SA}+2 \times \mathrm{A}+3 \times \mathrm{U}+$ $4 \times \mathrm{DA}+5 \times \mathrm{SDA}$ (in disfavour)

Where,

$\mathrm{SA}=$ Total number of respondents expressing their perception 'strongly agree' for the statement;

$\mathrm{A}=$ Total number of respondents expressing their perception 'agree' for the statement;

$\mathrm{U}=$ Total number of respondents expressing their perception 'undecided' for the statement;

DA $=$ Total number of respondents expressing their perception 'disagree' for the statement; and

SDA = Total number of respondents expressing their perception 'strongly disagree' for the statement.

Financial profitability for agricultural enterprises (i.e., crop, livestock, fisheries and homestead) was derived in terms of gross return, gross 
margin, net return and benefit cost ratio (undiscounted) as follows:

$$
\mathrm{GR}=\sum_{\mathrm{i}=1}^{\mathrm{n}} \mathrm{Q}_{\mathrm{i}} \mathrm{P}_{\mathrm{i}}
$$

Where,

$\mathrm{GR}_{\mathrm{i}}=$ Gross return from $\mathrm{i}^{\text {th }}$ product (Tk./unit);

$\mathrm{Q}_{\mathrm{i}}=$ Quantity of the $\mathrm{i}^{\text {th }}$ product (Tk./unit);

$\mathrm{P}_{\mathrm{i}}=$ Average price of the $\mathrm{i}^{\text {th }}$ product (Tk./unit); and $\mathrm{i}=1,2,3 \ldots \ldots \ldots \ldots, \mathrm{n}$.

Gross return of livestock was determined by adding income earned from sale of milk and cowdung, inventory changes and other purposes. The net change in inventory was estimated by using the following formula:

Net change in inventory $=($ Closing stock + Consumed/ gifted + Sold + Died $)-$ (Opening stock + Brought $)$

\section{Gross margin}

Gross margin was calculated by the difference between gross return and total variable costs; which is appeared as:

$\mathrm{GM}=\mathrm{GR}-\mathrm{TVC}$

Where,

GM = Gross margin; GR = Gross return; and TVC $=$ Total variable cost .

\section{Net return}

Net return considered fixed costs i.e., cost of land rent, interest on operating capital, etc. Net return was calculated by deducting all costs (variable and fixed) from the gross return. To estimate the financial profitability of different agricultural enterprises, profit equation of the following algebraic form was used:

$$
\pi=\sum_{i=1}^{n}\left(P_{Y} \cdot Y\right)-\sum_{i=1}^{n}\left(P_{x i} \cdot X_{i}\right)-T F C
$$

Where,

$\pi=$ Net return (Tk./unit); $\mathrm{P}_{\mathrm{y}}=$ Per unit price of the product (Tk./unit);

$\mathrm{Y}=\mathrm{Quantity}$ of the production per hectare/animal (unit);

$\mathrm{P}_{\mathrm{xi}}=$ Per unit price of the $\mathrm{i}^{\text {th }}$ inputs (Tk.);
$X_{i}=$ Quantity of the $i^{\text {th }}$ input per hectare (unit); TFC $=$ Total fixed cost (Tk./unit); and $\mathrm{i}=1,2,3, \ldots \ldots \ldots ., \mathrm{n}$ (number of inputs).

\section{Benefit cost ratio}

The benefit cost ratio (BCR) is a relative measure which was used to compare benefit accrued for each taka investment. BCR was estimated as a ratio of gross returns and gross costs. The formula of calculating BCR (undiscounted) is shown as below:

Benefit cost ratio $=$ Gross return $/$ Gross cost

\section{Results and Discussion}

\subsection{Socioeconomic characteristics of the farm households}

The survey was conducted among the households of which $93 \%$ were male and $7 \%$ were female in case of project farmers whereas $60 \%$ were male and $40 \%$ were female for the non-project farmers. In case of project farmers, $65.7 \%$ respondents aged within $15-55$ years. Again, in the case of non-project farmers, $49.7 \%$ persons were belonging to $15-55$ years. Nearby, $40.6 \%$ project farmers have passed secondary level. But, for non-project farmers it was only $34.8 \%$ (Table 1). For project farmers, on an average, $20.6 \%$ respondents engaged in agriculture as their main occupation and for nonproject farmers, it was $17.9 \%$. Households under project farmers, the average farm size were 0.60 hectare while non-project farmers have an average farm size of 0.57 hectare. Only $31.1 \%$ project farmers received training from BRDB, whereas non-project farmers received training from DAE and BAU on livestock rearing. From the tabular analysis (Table 1), it was found that socioeconomic characteristics of different categories of farmers i.e. project and non-project farmers. Overall educational status was better for project farmers than non-project farmers. The project farmers were more occupied than nonproject farmers. The average farm sizes were higher in project farmers than non-project farmers. Project farmers utilized their fallow land efficiently (Jannat, 2015). 


\subsection{Farmers' perceptions about 'one house one farm' approach}

Perception score for different relevant factors was calculated by using the perception index (PI). The mean score of each statement was also calculated. The PI for each statement has been arranged in rank order according to their extent of agreement which appears in Table 2. Perception index was found to vary from 77 to 206 for project farmers. Data in table 2 reveals the perception index score and the ranking of the statements based on the perception index. Project farmers ranked $1^{\text {st }}$ statement positively which scored 206 in favour. 'One house one farm' approach increases food production is essential to run project which got the $1^{\text {st }}$ rank among the statements. Training is essential to run 'one house one farm' approach which also got the $2^{\text {nd }}$ rank with the total PI of 204. Integration of different agricultural components (crop, fish, cattle, poultry and nursery) is essential statement got $3^{\text {rd }}$ rank with the total PI of 193. But, 'Loan given by the government is not necessary to be paid back' got the last rank among the statements with the total PI 77 in disfavour situation. The majority of the project farmers had moderate or less favourable perception about 'one house one farm'. Table 2 shows that 'Government gives credit support to the landless poor farmers' obtained highest PI (168) and stood first in the rank order for the non-project farmers. Majority of the project farmers had moderate perception towards the project because it has impact on their livelihood which is slightly positive. But, the perception of the non-project farmers was slightly positive. This led to the conclusion that for the better adoption of this approach among the non-project farmers, more favorable perception is required through providing training.

\subsection{Profitability analysis of different agricultural enterprises}

One of the most important aspects of this study was to evaluate the profitability of crop (Aus, Aman and Boro rice), livestock, fish and homestead production for different categories of farmers. In case of rice, non-rice, fish and homestead enterprises, profitability were calculated in terms of per hectare basis; while for livestock enterprises (large and small animal), per number basis were applied.

Table 1. Socioeconomic characteristics of the sample farm household

\begin{tabular}{|c|c|c|c|}
\hline \multicolumn{2}{|l|}{ Particulars of respondents } & Project farmers & Non-project farmers \\
\hline \multicolumn{4}{|c|}{ Family size, age, education level, occupational status, land type and farm household } \\
\hline \multirow{2}{*}{ Respondents sex category (\%) } & Male & 93 & 60 \\
\hline & Female & 7 & 40 \\
\hline \multicolumn{2}{|l|}{ Family size (no.) } & 4.5 & 4.3 \\
\hline \multicolumn{2}{|c|}{ Age $(15-55$ years $)(\%)$} & 65.7 & 49.7 \\
\hline \multirow{2}{*}{\multicolumn{2}{|c|}{$\frac{\text { Educational level (years of schooling) }}{\text { Agriculture }}$}} & 40.6 & 34.8 \\
\hline & & 20.6 & 17.9 \\
\hline \multirow[t]{2}{*}{ Occupational status (\%) } & Small business & 5.4 & 2.2 \\
\hline & Wage labour & 7.8 & 8.9 \\
\hline Land holding (ha) & Average & 0.60 & 0.57 \\
\hline \multirow{6}{*}{$\begin{array}{l}\text { Area and number of } \\
\text { agricultural enterprises }\end{array}$} & Crop area (ha) & 0.39 & 0.34 \\
\hline & Livestock Large animal & 4.31 & 2.62 \\
\hline & (no.) $\quad$ Small animal & 40.8 & 29.5 \\
\hline & Fisheries (ha) & 0.02 & 0.03 \\
\hline & Homestead (ha) & 0.69 & 0.57 \\
\hline & Agroforestry (no.) & 13.4 & 8.9 \\
\hline \multicolumn{2}{|l|}{ Training exposure $(\%)$} & 31.1 & 11.1 \\
\hline
\end{tabular}

Source: Field survey, 2015. 
Table 2. Perception of the farmers on 'one house one farm' approach (statement-wise score)

\begin{tabular}{|c|c|c|c|c|c|}
\hline \multirow{2}{*}{$\begin{array}{l}\text { Sl. } \\
\text { No. }\end{array}$} & \multirow[t]{2}{*}{ Statements } & \multicolumn{2}{|c|}{$\begin{array}{l}\text { Project } \\
\text { farmers }\end{array}$} & \multicolumn{2}{|c|}{$\begin{array}{l}\text { Non-project } \\
\text { farmers }\end{array}$} \\
\hline & & PI & Rank & PI & Rank \\
\hline 1 & 'One house one farm' approach increases food production & 206 & 1 & 91 & 17 \\
\hline 2 & $\begin{array}{l}\text { 'One house one farm' approach can ensure nutritional security of } \\
\text { the households }\end{array}$ & 187 & 6 & 125 & 10 \\
\hline 3 & $\begin{array}{l}\text { Daily consumption of the family members can be meet up by the } \\
\text { approach }\end{array}$ & 180 & 8 & 83 & 18 \\
\hline 4 & $\begin{array}{l}\text { Practicing 'one house one farm' approach helps the poor farmers } \\
\text { to increase their income }\end{array}$ & 192 & 4 & 95 & 16 \\
\hline 5 & The approach cannot help the farmers in short duration (-) & 106 & 16 & 98 & 15 \\
\hline 6 & Different product ensures more financial security & 169 & 11 & 156 & 4 \\
\hline 7 & $\begin{array}{l}\text { Government gives credit support to the landless and marginal } \\
\text { farmers }\end{array}$ & 189 & 5 & 168 & 1 \\
\hline 8 & Farmers can get quality seed from the government & 163 & 12 & 118 & 12 \\
\hline 9 & Loan given by the govt. is not necessary to be paid back (-) & 77 & 18 & 115 & 13 \\
\hline 10 & Training is essential to run 'one house one farm' approach & 204 & 2 & 165 & 2 \\
\hline 11 & $\begin{array}{l}\text { Farmers having less than one hectare land cannot follow 'one } \\
\text { house one farm' approach }\end{array}$ & 114 & 15 & 105 & 14 \\
\hline 12 & $\begin{array}{l}\text { Political affiliation is required to get input supply from the } \\
\text { government (-) }\end{array}$ & 100 & 17 & 160 & 3 \\
\hline 13 & $\begin{array}{l}\text { Integration of different agricultural components (crop, fish, cattle, } \\
\text { poultry and nursery) are essential }\end{array}$ & 193 & 3 & 124 & 11 \\
\hline 14 & $\begin{array}{l}\text { Income generating from non-agricultural activities are not } \\
\text { included in 'one house one farm' approach }(-)\end{array}$ & 124 & 14 & 148 & 6 \\
\hline 15 & $\begin{array}{l}\text { Homestead gardening is an essential component of 'one house } \\
\text { one farm' approach }\end{array}$ & 171 & 10 & 137 & 8 \\
\hline 16 & $\begin{array}{l}\text { Field level agents of BRDB help the famers to adopt 'one house } \\
\text { one farm' approach }\end{array}$ & 174 & 9 & 134 & 9 \\
\hline 17 & $\begin{array}{l}\text { Extension activities of DAE help the farmers to adopt 'one house } \\
\text { one farm' approach }\end{array}$ & 185 & 7 & 149 & 5 \\
\hline 18 & Different organizations give training only & 160 & 13 & 144 & 7 \\
\hline
\end{tabular}

Source: Authors' estimation based on field survey, 2015.

Note: (-) = Disfavour situation

All costs and returns were calculated for the duration of one year for both project and nonproject farmers. It is important to consider the economic value when considering a relatively new enterprises on a farm households as it will have current effects on the livelihood. A convenient way to assess the profitability was to calculate gross margin.
Data in table 3 shows the overall situation of the different enterprises i.e., incurred costs, earned profits and the comparison between the project and non-project farmers. The estimated total costs for producing Aus, Aman and Boro were Tk. 80337.4, Tk. 59490.2 and Tk. 82028.8 in case of project farmers, respectively. On the other hand, non-project farmers incurred Tk. 
79915.1, Tk. 69479.2 and Tk. 83790.3 for Aus, Aman and Boro rice, respectively. Boro rice production involved the highest level of cost for both categories of farmers. Net returns per hectare of Aus, Aman and Boro rice were estimated at Tk. 17084.9, Tk. 21893.4 and Tk. 40922.0 where these were estimated at $\mathrm{Tk}$. 12050.9, Tk. 7717.7 and Tk. 15658.62 for project farmers and for non-project farmers, respectively (Table 3 ).

The overall BCR (undiscounted) of Aus, Aman and Boro rice farming of project farmers were $1.28,1.29$ and 1.50 indicating that rice farming is profitable. On the other hand, the BCR were 1.15, 1.11 and 1.19 for Aus, Aman and Boro rice in case of non-project farmers which indicate that, the rice farming is also profitable (Table 3).
For large animal and small animal rearing, project farmers' average cost was higher (Tk.23770.8 and Tk. 6319.6 per households) than non-project farmers (Tk. 18216.1 and Tk.4592.6 ). The estimated total return per large animal per year stood at Tk. 30044.1 and Tk. 19692.8 for project and non-project farmers, individually. The estimated return per small animal per year stood at Tk. 1070.8 and Tk. 317.9 for project and non-project farmers, correspondingly. The overall BCR (undiscounted) of large animal of project farmers was 1.26 indicating that large animal rearing is profitable. On the other hand, the BCR was 2.08 for non-project farmers which indicate that, the large animal is also profitable (Table 3). Similarly, BCR of small animal were 1.16 and 1.06 for project and non-project farmers, respectively.

Table 3. Profitability of different crop and non-crop enterprises (Tk./ households)

\begin{tabular}{lccccccc}
\hline \multirow{2}{*}{ Items } & Aus & Aman & Boro & $\begin{array}{c}\text { Large } \\
\text { animal }\end{array}$ & $\begin{array}{c}\text { Small } \\
\text { animal }\end{array}$ & Fisheries & $\begin{array}{c}\text { Homestead } \\
\text { farming }\end{array}$ \\
\cline { 2 - 6 } & \multicolumn{7}{c}{ Project farmers } \\
\hline Total variable cost & 44882.2 & 27146.4 & 48384.4 & 15042.0 & 3340.0 & 16890.0 & 6547.1 \\
Total fixed cost & 35455.2 & 32343.8 & 33644.4 & 8728.8 & 2979.6 & 5023.5 & 5917.0 \\
Total cost & 80337.4 & 59490.2 & 82028.8 & 23770.8 & 6319.6 & 21913.5 & 12464.1 \\
Gross return & 97422.3 & 81383.6 & 122951.1 & 53814.1 & 7390.4 & 34260.0 & 20975.0 \\
Gross margin & 52540.1 & 54237.2 & 74566.7 & 38772.13 & 4050.4 & 17370.0 & 14428.0 \\
Net return & 17084.9 & 21893.4 & 40922 & 30044.1 & 1070.8 & 12346.5 & 8511.0 \\
BCR & 1.28 & 1.29 & 1.50 & 1.26 & 1.16 & 1.56 & 1.68 \\
\hline Total variable cost & 46644.7 & 36370.0 & 49937.2 & 11037.0 & 2362.0 & 17721.6 & 6986.0 \\
Total fixed cost & 33270.3 & 33109.2 & 33753.1 & 7179.1 & 2230.6 & 5139.8 & 5978.0 \\
Total cost & 79915.0 & 69479.2 & 83690.3 & 18216.1 & 4592.6 & 22861.4 & 12964.0 \\
Gross return & 91966.0 & 77196.9 & 99348.8 & 37909.0 & 4910.4 & 32100.0 & 17530.0 \\
Gross margin & 51321.3 & 40826.9 & 49411.7 & 26872.0 & 2548.6 & 14378.4 & 10544.0 \\
Net return & 12050.9 & 7717.7 & 15658.6 & 19692.8 & 317.9 & 9238.5 & 4566.0 \\
BCR & 1.15 & 1.11 & 1.20 & 2.08 & 1.06 & 1.40 & 1.35 \\
\hline
\end{tabular}

Source: Authors' estimation based on field survey, 2015. 
The picture of fish production is reverse. Nonproject farmers incurred cost for fish production Tk. 22861.4 while it was Tk. 21913.5 per households for project farmers. Likely, for homestead farming, non-project farmers incurred Tk. 12964 and project farmers incurred Tk. 12464.1. Average net returns of fish farming per hectare were estimated at Tk. 12346.5 and Tk. 9238.5 for project and non-project farmers, respectively. BCR (undiscounted) of project farmers was 1.56 indicating that fish farming is profitable. On the other hand, the BCR was 1.40 for non-project farmers which indicate that, the fish farming is also profitable (Table 3). It can be concluded that project farmers earned higher return than non-project farmers for every enterprises except large animal rearing. In this case, non-project farmers were more profitable, because, most of the non-project farmers got technical support and training from BAU. After implantation of the 'one house one farm' project, most of the project farmers were trained up for crop and homestead farming and they bought calves for rearing. That's why; the BCR of the project farmers was less than non-project farmers in case of large animal rearing. But, in case of other enterprises, the project farmers are better off than the non-project farmers (Jannat, 2015).

\subsection{Income generation and employment creation}

The labour hour spent by both men and women has increased in the research sites. Male household members spent more time than their female counterpart in the field. Data in table 4 represents that on average, project farmers worked 4.5 hours per day while non-project farmers worked 3.4 hours per day. The average working hours/day for the respondents was 2.1 and 1.7, respectively for project and non-project farmers. The highest employment duration for the respondents was 106.0 man-days/year for the project farmers and for non-project farmers, it was 52.0 man-days/year. Therefore, it can be revealed that project farmers spent more time in work and their wage rate was also higher in comparison to the non-project farmers. Thus, 'one house one farm' project creates more income and employment opportunity in the study areas.

Table 4. Employment pattern on yearly basis for farm households

\begin{tabular}{|c|c|c|c|c|c|c|c|c|}
\hline \multirow[b]{2}{*}{ Farming systems } & \multicolumn{4}{|c|}{ Working hours/ day } & \multicolumn{4}{|c|}{ Duration (man-days/year) } \\
\hline & Self & $\begin{array}{c}\text { Wife/ } \\
\text { husband }\end{array}$ & $\begin{array}{c}\text { Son/ } \\
\text { daughter }\end{array}$ & $\begin{array}{l}\text { Hired } \\
\text { labour }\end{array}$ & Self & $\begin{array}{c}\text { Wife/ } \\
\text { husband }\end{array}$ & $\begin{array}{c}\text { Son/ } \\
\text { daughter }\end{array}$ & $\begin{array}{l}\text { Hired } \\
\text { labour }\end{array}$ \\
\hline \multicolumn{9}{|c|}{ Project farmers } \\
\hline Crop farming & 4.5 & 0.7 & 2.4 & 2.7 & 132.5 & 26.5 & 84.2 & 94.5 \\
\hline Livestock rearing & 1.8 & 2.2 & 1.9 & 0.2 & 118.4 & 43.8 & 56.8 & 18.3 \\
\hline Fish farming & 2.1 & 0.4 & 1.3 & 0.7 & 126.5 & 16.8 & 43.1 & 26.3 \\
\hline Homestead farming & 0.1 & 1.3 & 1.2 & 0.7 & 46.6 & 25.8 & 39.2 & 24.0 \\
\hline Average & 2.1 & 1.15 & 1.7 & 1.1 & 106.0 & 28.2 & 55.8 & 40.8 \\
\hline \multicolumn{9}{|c|}{ Non-project farmers } \\
\hline Crop farming & 3.4 & 0.6 & 2.1 & 2.2 & 104.5 & 24.2 & 46.5 & 54.2 \\
\hline Livestock rearing & 1.4 & 2.0 & 1.5 & 0.2 & 35.3 & 36.8 & 28.8 & 16.8 \\
\hline Fish farming & 2.0 & 0.25 & 1.1 & 0.7 & 46.3 & 13.1 & 21.8 & 23.1 \\
\hline Homestead farming & 0.1 & 1.10 & 1.0 & 0.10 & 22.0 & 29.2 & 15.8 & 17.2 \\
\hline Average & 1.7 & 1.0 & 1.42 & 0.8 & 52.0 & 25.8 & 28.2 & 27.8 \\
\hline
\end{tabular}

Source: Field survey, 2015. 
Table 5. Level of income generation by the sample farms

\begin{tabular}{lccc}
\hline Income sources & Project farmers & $\begin{array}{c}\text { Non-project } \\
\text { farmers }\end{array}$ & $\begin{array}{c}\text { Mean difference } \\
\text { (Tk.) }\end{array}$ \\
\cline { 2 - 3 } & Amount $($ Tk.) & Amount $($ Tk.) & \\
\hline Total farm income & $132454.5\left(7.048^{* * *}\right)$ & $98696.4\left(5.31^{* * *}\right)$ & 33758.1 \\
Total non-farm income & $174741.7\left(-1.53^{*}\right)$ & $132668.0(-2.54 * *)$ & 42073.7 \\
Total income & 307196.2 & 231364.5 & 75831.7 \\
\hline
\end{tabular}

Source: Authors' calculation based on field survey, 2015.

Note: $* * *$ Significant at 1 percent level; ** Significant at 5 percent level and $*$ Significant at 10 percent level.

Table 4 represents that crop farming is the largest source of farm income for all the farming systems. They also gain income from livestock and poultry rearing, fish farming, homestead vegetables and forestry. The average annual total income per household of project and non-project farmers was Tk. 307196.2, and Tk. 231364.5, respectively (Table 5). The average annual total income from farm activities of project and nonproject farmers were Tk. 132454.5 and Tk. 98696.5, respectively while it was Tk. 174741.7 and Tk. 132668.0 for non-farm activities. The average farm household income of the project farmer was increased compared to non-project farmers which is statistically significant at $1 \%$ level. On the other hand, non-farm income was decreased slightly but it is not statistically significant. The overall situation of income and employment status was improved due to the adoption of 'one house one farm' approach. This approach helped the farmers by providing different types of support to the project farmers in the study areas. These findings represented that 'one house one farm' project had a great impact on farm households' income in comparison to non-project farmers (Jannat, 2015).

\subsection{Policy options for overcoming constraints and exploring possible opportunities}

In the study areas, farmers were adopting 'one house one farm' approach by the help of BRDB taking 2 or 3 days training out of 7 days training in one month. Some beneficiaries were willing to take training but lack of some collaboration with BRDB, they were not able to make it. On the other hand, some farmers were not willing to train themselves of practicing 'one house one farm' because of untimely training.About $17.8 \%$ and $8.8 \%$ project farmers and non-project farmers informed on this problem, respectively (Table 6). Farmers' access to credit is one of the major problems in the study areas. About $44.5 \%$ of project farmers and $51.2 \%$ non-project farmers conveyed about the credit related problem. Social problems associated with agriculture cannot be separated from external social pressures. Occasionally, farmers faced such type of problem. Due to political limitations, farmers were deprived from loan which was provided by BRDB to practice the 'one house one farm'; although, the provision of the project was to give loan to the farmers with each terms and conditions. About $8.9 \%$ project farmers reported on this problem while it was $15.5 \%$ for non-project farmers (Table 6). Both categories of farmers indicated some probable suggestions to solve their problems stated. Both project and non-project farmers suggested that training should be provided by skilled officials, loan disbursement process should be changed with easy way and minimum interest rate. The support and services are specifically needed for the landless and marginal farmers to increase their agricultural productivity. Farmers also suggested for improving the marketing facilities and building up farmers' cooperative so that they can improve their livelihood status and reduce the poverty level. 
Table 6. Stated constraints and the probable options for overcoming those constraints

\begin{tabular}{|c|c|c|c|c|}
\hline \multirow[b]{2}{*}{ Items } & \multicolumn{2}{|c|}{ Project farmers } & \multicolumn{2}{|c|}{ Non-project farmers } \\
\hline & $\begin{array}{c}\text { No. of } \\
\text { respondents }\end{array}$ & $\%$ & $\begin{array}{c}\text { No. of } \\
\text { respondents }\end{array}$ & $\%$ \\
\hline \multicolumn{5}{|c|}{ Constraints } \\
\hline Training related problems & 8 & 17.8 & 4 & 8.8 \\
\hline Credit related problems & 20 & 44.5 & 23 & 51.2 \\
\hline Support and service related problems & 6 & 13.3 & 7 & 15.5 \\
\hline Marketing problems & 7 & 15.5 & 4 & 8.9 \\
\hline Social problems & 4 & 8.9 & 7 & 15.5 \\
\hline Total & 45 & 100.0 & 45 & 100.0 \\
\hline \multicolumn{5}{|c|}{ Probable opportunities } \\
\hline To provide training by skilled officials & 9 & 20.0 & 8 & 17.8 \\
\hline $\begin{array}{l}\text { To provide sufficient amount of loan } \\
\text { with easier procedure and lower } \\
\text { interest rate }\end{array}$ & 18 & 40.0 & 23 & 51.1 \\
\hline $\begin{array}{l}\text { To provide scientific knowledge and } \\
\text { extension services timely }\end{array}$ & 8 & 17.8 & 7 & 15.6 \\
\hline To improve marketing facilities & 7 & 15.5 & 4 & 8.8 \\
\hline $\begin{array}{l}\text { To build up farmers' cooperative and } \\
\text { ensure political stability }\end{array}$ & 3 & 6.7 & 3 & 6.7 \\
\hline Total & 45 & 100.0 & 45 & 100.0 \\
\hline
\end{tabular}

Source: Authors' calculation, 2015.

\section{Conclusions}

By the adoption of 'one house one farm' approach, project farmers got more opportunities to improve their economic condition and livelihood status through diversified income generating activities than non-project farmers. Majority of the project farmers had moderate perception towards the project because it has impact on their livelihood which is positive. The analysis further shows that project farmers earned higher return than non-project farmers for each enterprise except large animal rearing. In this case, non-project farmers were more profitable as most of them got technical support and training from BAU. Project farmers spent more time in work and their wage rate was also higher in comparison to the non-project farmers. Thus, 'one house one farm' project creates more income and employment opportunity. Although farmers face many problems to get credit, training, technical support from the government, these can be solved by the concerned authorities through proper monitoring.

\section{References}

Anonymous, 2014. Project Digest: One House One farm Approach. Bangladesh Rural Development Board (BRDB). Ministry of Local Government, Rural Development and Cooperatives, Government of the People's Republic of Bangladesh.

Islam, I., Haque, M. J., Miah M. A. M. and Sheheli, S. 2013. Competency Assessment of the Farmers on the Application of One House One Farm Approach. Progressive Agriculture, 24:291-299. 
Islam, S., Uddin, M.T., Akteruzzaman, Rahman, M. and Haque, M.A. 2011. Profitability of Alternate Farming Systems in Dingapota Haor Area of Netrokona District. Progressive Agriculture, 22(1 \& 2):223239.

Jannat, A. 2015. 'One House One Farm' Project and Its Impact on Farmers' Livelihood in Selected Areas of Mymensingh District. M.S. Thesis, Department of Agricultural Economics, Bangladesh Agricultural University, Mymensingh-2202.

Rakib, M. F. I. 2012. A Comparative Economic Study on BRRI Dhan 51 and BR11 Rice Production in Some Selected Areas of Mymensingh District. M.S. Thesis, Department of Agricultural Economics, Bangladesh Agricultural University, Mymensingh-2202.

Roy, B. S. 2009. Farmers' Perception of the Effect of IPM for Sustainable Crop Production. M.S. Thesis, Department of Agricultural Extension Education, Bangladesh Agricultural University, Mymensingh-2202.
Sapna, S. 2012. An Economic Study of 'One House One Farm' in Some Selected Areas of Jamalpur District. M.S. thesis, Department of Agricultural Economics, Bangladesh Agricultural University, Mymensingh-2202.

Trading Economics, 2015. Bangladesh GDP Growth Rate. (URL: http://www.tradingeconomics.com/bangla desh/gdp-growth).

Ullah, S.M.A., Farouque, M.G. and Rahman, M.Z. 2013. Problem Faced by the Farmers' In Practicing 'One House One Farm' Approach. Journal of Agroforestry Environment, 7 (1): $77-$

80 .

Ullah, S.M.A. 2011. Farmers' Perception of 'One House One Farm' Approach. M.S. thesis, Department of Agricultural Extension Education, Bangladesh Agricultural University, Mymensingh-2202. 